\title{
Analysis of the Need for Mechanical and Instrumentation Equipment in the Utilization of Gas Wells in Balun Field
}

\author{
Kasturi $^{*}{ }^{*}$, Hafid Suharyadi ${ }^{2}$, Dwi Mulyono ${ }^{3}$ \\ 1,2,3 Politeknik Energi dan Mineral [PEM] Akamigas, Jln Gadjah Mada No. 38, Cepu 58315
}

\begin{abstract}
The utilization of old gas wells in Balun field has the potential to improve the welfare of the people in Cepu District and the surrounding areas in meeting their daily gas needs. However, the challenge of these old unutilized gas wells has risks and impacts on the environment, such as the possibility of gas leak causing fires. This study aimed to analyze the potential of old gas wells and to analyze the impact of risks on the areas around the old gas wells, which will be passed through the gas network, and where the gas processing units will be established. In this analysis, the results of the gas processing process would be distributed to Cepu District to meet household fuel needs. In addition, the use of these old gas wells is also to provide education to students regarding gas processing and distribution. The analysis of the utilization of old gas wells began with mapping of environmental conditions, distribution pipeline systems, and gas processing locations. The mechanical equipment requirements for the model, pipeline design, and processing unit would be presented. Next, the need for the instrumentation system would improve the transmission system and processing unit with reference to ease of operation and safety. In addition, budget requirements and flow diagram were needed to facilitate further programs when building pipelines and the desired gas processing unit.
\end{abstract}

Keywords: Gas well, Balun field, mechanical equipment, gas processing unit

kasturi@esdm.go.id

\section{Introduction}

A. Background

Geological conditions and petroleum aspects of Cepu region and its surroundings are very interesting as learning objects for academics and practitioners in the oil and gas sector. Up to now, oil and gas exploitation activities in Cepu Block (Figure 1) are still ongoing, both in the production and exploration stages. There are several mining-licensed areas that are still active with exploitation activities taking place, especially in fields with prospective reserves for large-scale companies. Meanwhile, oil and gas reserves in a smaller amount are not exploited, one of which is the Balun Gas Field. The Balun field mostly produces natural gas which was previously exploited and used for gas supply in the Cepu area. With the latest status of the Cepu Block, the wells from the Balun field have not been utilized until now.

Meanwhile, Politeknik Energi dan Mineral Akamigas (PEM Akamigas), a vocational education institution in the oil and gas sector, needs a place for students and lecturers to practice training their competencies on the field campus. 
PEM Akamigas sees the need to reuse the old wells in Balun field as learning wells. As the initial stage of realizing the use of wells in Balun field, a Feasibility Study is required to provide feasibility information related to technical, safety, social and economic aspects. As part of the feasibility study, research is needed with the scope of the initial design in the mechanical and instrumentation parts.

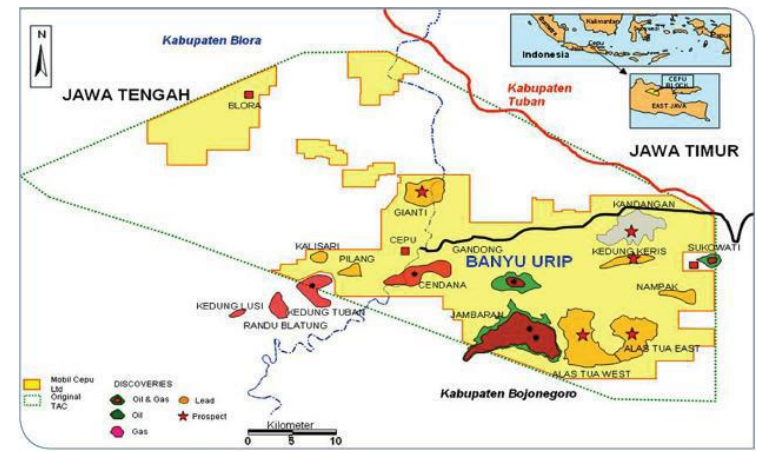

Figure 1. Map showing the location of Cepu Block (Peta WKP 2008 IAGI).

\section{B. Research Concept}

This research activity was oriented towards utilization and completion goals, namely:

- Determining the need for mechanical equipment which includes piping systems, pumps, compressors, tanks and vessels or containers.

- Determining the need for instrumentation equipment which includes the need for measuring equipment, control equipment and safety equipment.

- Determining the type of electrical equipment, ranging from electric motors, installations and so on.

- Providing approximate cost for procurement and construction of mechanical and instrumentation facilities.

To support the above activities, an initial feasibility study was carried out for the utilization of gas wells in Balun Field. Which will produce research output in the forms of:

a. List of quantity and initial technical specifications of mechanical equipment, from piping systems, pumps, compressors, tanks, to vessels or containers.

b. List of quantity and initial technical specifications of instrumentation equipment, as measuring instruments, control devices and safety equipment.

c. List of quantity and initial technical specifications of electrical equipment, starting from electric motors, installations and so on.

d. The figure of mechanical and instrumentation equipment arrangement.

e. Take Off materials.

f. Initial Cost Estimation.

\section{Material and Methods}

In carrying out this research, a research method would be carried out with the following activity stages:

\section{A. Literature Study}

Looking for references needed to support the initial activities of research on mechanical and instrumentation equipment requirements.

\section{B. Making Process-Flow Diagram}

Making Process-Flow Diagram aimed to make it easier to realize the real conditions of the equipment that will be needed, as well as to facilitate in choosing the equipment needed properly.

C. Making Piping and Instrumentation System (P\&ID )

The purposes of making P\&ID were for:

- Process control is the spirit of a process, because from here the variable can be controlled and secured by the process requirements as well as the product requirements according to the specifications.

From this figure, we can know the need for mechanical equipment, instrumentation equipment, whether as a measuring tool, a control device, or a safety device. As well as knowing the need for the cost of procuring mechanical equipment, which is needed to build a processing unit. 


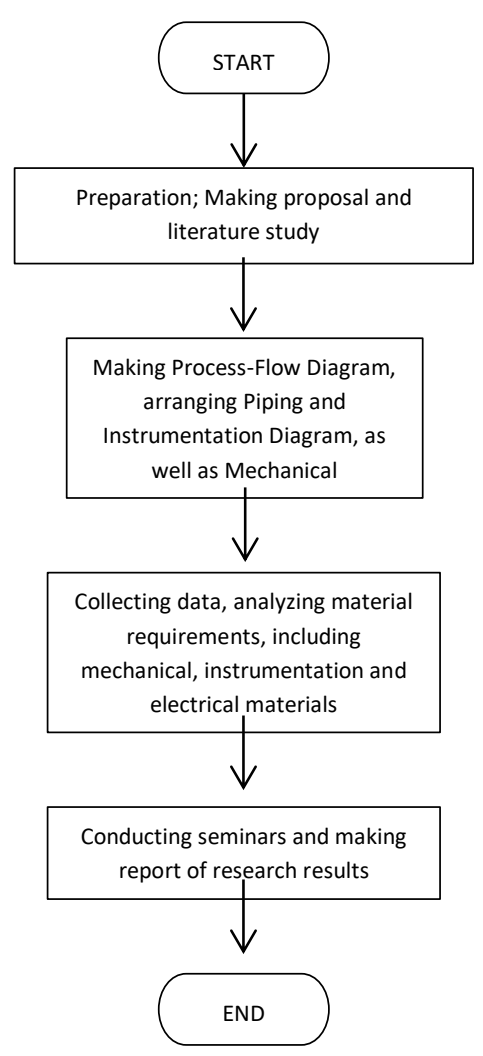

Figure 2. Flow diagram of the research.

\section{Results and Discussion}

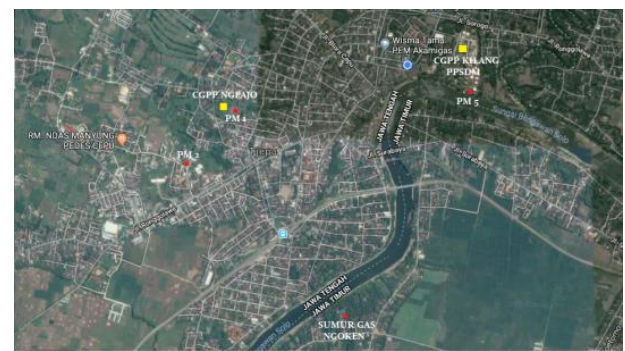

Figure 3. Location of gas wells in Balun Field (map prepared using Google earth).

From the checking of conditions of the field locations to the gas field in Balun block, finally the most effective one was chosen if the processing is carried out. The purpose of this selection was to refer to the costs and yields that are more economical, easy to work with and safe. The first point was the PM.1 and PM.2 wells, which are located close together and from the latest data these wells are ready for production.
The following is the maps of the location and piping path that will be passed in order to produce the cheapest and most cost-effective process.

From the field conditions and the processing unit object, there is a choice of gas processing located in the Nglajo area as the Nglajo Central Gas Processing Plant (CGPP Nglajo) by taking gas from PM 1 and PM 2 wells as follows

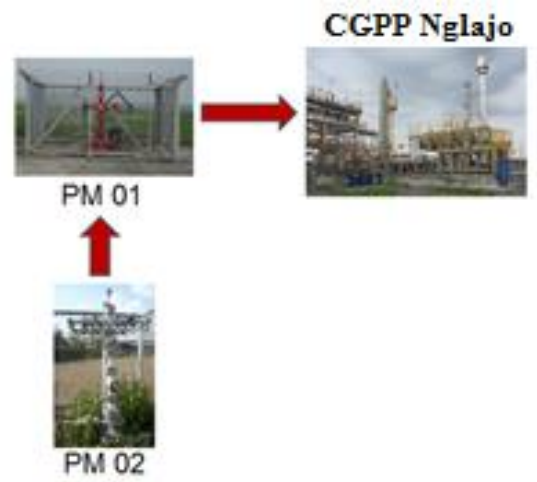

Figure 4. Process-flow diagram of CGPP Nglajo.

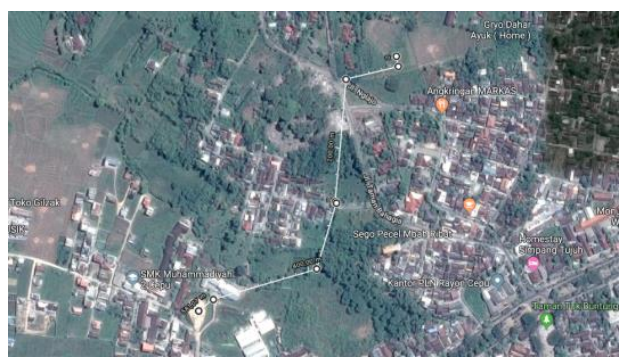

Figure 5. Pipeline to CGPP Nglajo (map prepared using Google earth).

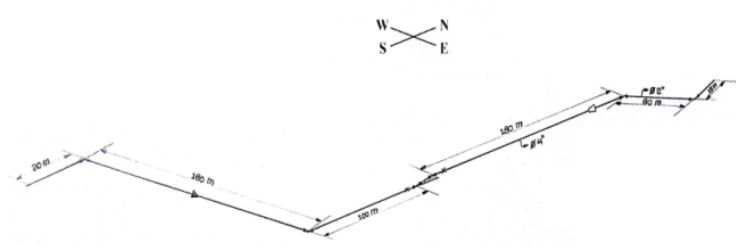

Figure 6. Isometric of PM 2 to CGPP Nglajo.

The results of the mapping of the piping system road map in Figure 5 and Figure 6 are isometric, can calculate the amount of mechanical material needed and the estimated cost of making the installation. 


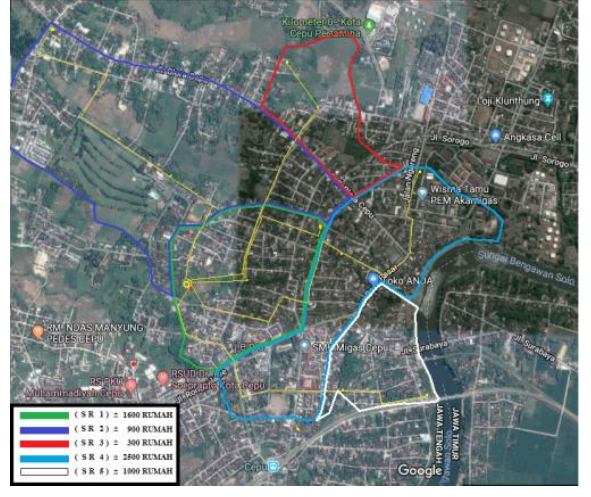

Figure 7. Distribution of consumers of gas products (map prepared using Google earth).

The data and model shown in Figure 7 show that the distribution of gas fuel users is quite dense, especially in the Cepu and Balun Districts. This amount and distribution becomes a reference for designing gas processing units with certain capacities, as well as processing techniques related to the separation of gas by-products.

The design of mechanical equipment and instrumentation equipment at the Central Gas Processing Unit (CGPP) is shown in Figure 8. Rrequirements for instrumentation equipment and its costs are shown in Table 1. and 2.

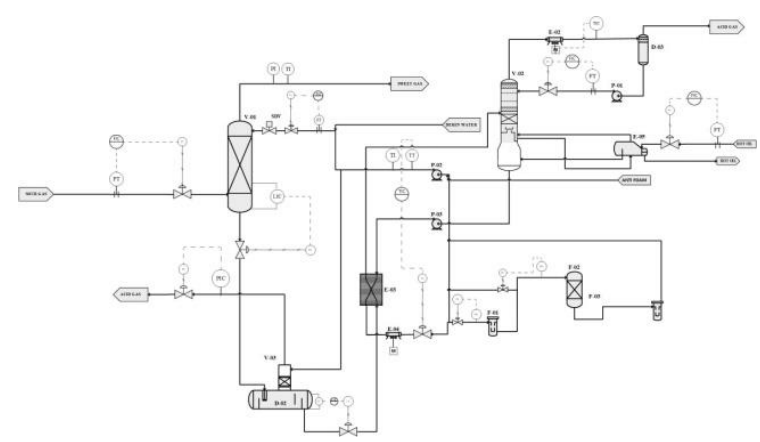

Figure 8. Model of CGPP unit.

Table 1. List of mechanical equipment and the costs.

\begin{tabular}{|c|l|l|r|}
\hline No. & $\begin{array}{l}\text { Type of } \\
\text { Material }\end{array}$ & Specification & $\begin{array}{c}\text { Amount of Price } \\
\text { (IDR) }\end{array}$ \\
\hline 1 & $\begin{array}{l}\text { HP } \\
\text { Separator }\end{array}$ & $\begin{array}{l}\text { Dimension } 7.6 \\
\mathrm{x} 2.2 \times 2.4 \mathrm{~m} \\
\text { capacity } 300 \\
\mathrm{~m}^{3} / \mathrm{D}\end{array}$ & $900,000,000$ \\
\hline 2 & $\begin{array}{l}\text { LP } \\
\text { Separator }\end{array}$ & $\begin{array}{l}\text { Dimension } 7.6 \\
\mathrm{x} 2.2 \times 2.4 \mathrm{~m}\end{array}$ & $900,000,000$ \\
\hline
\end{tabular}

\begin{tabular}{|c|c|c|c|}
\hline & & $\begin{array}{ll}\text { capacity } & 300 \\
\mathrm{~m}^{3} / \text { Day }\end{array}$ & \\
\hline 3 & $\begin{array}{l}\text { Gas } \\
\text { Scrabber }\end{array}$ & $\begin{array}{ll}316 \quad \text { L } & \text { SS , } \\
12000 & \\
230000 & \\
\mathrm{~m} 3 / \mathrm{jam} & \\
\end{array}$ & $600,000,000$ \\
\hline 4 & $\begin{array}{l}\text { Inlet } \\
\text { Cooler }\end{array}$ & $\begin{array}{l}\text { Forced draft } \\
\text { Single fan } \\
\text { Fan sizes } 48^{\prime \prime} \\
\text { to } 168^{\prime \prime} \\
\text { diameter } \\
\text { Engine or } \\
\text { electric motor } \\
\text { driven } \\
\text { Belt drive } \\
\text { Cooling } \\
\text { surface area up } \\
\text { to 75,000 } \mathrm{ft}^{2} \\
\text { Up to } 7 \\
\text { individual } \\
\text { services } \\
\text { Skid mounted }\end{array}$ & $996,000,000$ \\
\hline 5 & $\begin{array}{l}\text { Filter } \\
\text { Separator }\end{array}$ & $\begin{array}{l}\text { Dimension } 7.6 \\
\text { x } 2.2 \times 2.4 \mathrm{~m} \\
\text { capacity } 300 \\
\mathrm{~m}^{3} / \text { Day }\end{array}$ & $900,000,000$ \\
\hline 6 & $\begin{array}{l}\text { Gas } \\
\text { Coalescer }\end{array}$ & $\begin{array}{l}\text { Dimension } \\
2 \times 1.8 \times 2.2 \mathrm{~m} \\
\text { capacity } 3500 \\
\mathrm{~m}^{3} / \mathrm{h}\end{array}$ & $600,000,000$ \\
\hline 7 & $\begin{array}{l}\text { Demin } \\
\text { Water } \\
\text { Pump }\end{array}$ & $\begin{array}{l}\text { Cast } \\
\text { Iron/ss304/ss } \\
316 \text {, capacity: } \\
4-1200 \mathrm{~m}^{3} / \mathrm{h} \\
\text { head: } 8-150 \mathrm{~m} \\
\text { speed: 2900, } \\
\text { 1450r/min } \\
\text { power: 0.75- } \\
250 \mathrm{~kW} \\
\text { flange: } \\
350 \mathrm{~mm} \\
\text { medium temp.: } \\
\leq 80^{\circ} \mathrm{C}\end{array}$ & $210,000,000$ \\
\hline 8 & $\begin{array}{l}\text { Pre Wash } \\
\text { Column }\end{array}$ & & $140,000,000$ \\
\hline 9 & Pipe & $\begin{array}{l}\text { Carbon Steel } \\
2 ", \text { Sch } 40\end{array}$ & $106,215,000$ \\
\hline 10 & $\begin{array}{l}\text { Flange Slip } \\
\text { On }\end{array}$ & $\begin{array}{l}\text { RF, 2", ASTM } \\
105, \text { ASA } 300\end{array}$ & $2,000,000$ \\
\hline 11 & Elbow $90^{0}$ & A $234,2 ", \# 300$ & $2,000,000$ \\
\hline 12 & Elbow $45^{0}$ & A 234, 2", \#300 & $1,500,000$ \\
\hline 14 & Valve & $\begin{array}{l}\text { A126, \#300, 2" } \\
\text { globe Valve }\end{array}$ & $3,000,000$ \\
\hline 15 & $\begin{array}{l}\text { Check } \\
\text { Valve }\end{array}$ & $\begin{array}{ll}\text { ANSI } & \text { Class } \\
\# 300,2 " & \end{array}$ & $4,010,000$ \\
\hline 16 & Strainer & $\begin{array}{l}\text { Cast Iron DIN } \\
\text { pn16, 2" }\end{array}$ & $1,750,000$ \\
\hline \multicolumn{3}{|r|}{ Total Cost } & $4,228,475,000$ \\
\hline
\end{tabular}


Table 2. List of instrumentation equipment and the costs.

\begin{tabular}{|c|c|c|c|}
\hline No. & $\begin{array}{c}\text { Name of } \\
\text { Equipment }\end{array}$ & Type & Price ( IDR ) \\
\hline 1 & $\begin{array}{l}\text { Thermocoupl } \\
\mathrm{e}\end{array}$ & Type J & 168,000 \\
\hline 2 & $\begin{array}{l}\text { Level } \\
\text { Transmitter }\end{array}$ & $\begin{array}{l}\text { DP Transmitter } \\
\text { Yokogawa } \\
0.04 \text { accuracy } \\
90 \mathrm{~ms} \text { response } \\
\text { time } \\
\text { Range } 0-10000 \\
\text { mmh2o } \\
\text { Supply } 24 \text { VDC }\end{array}$ & $17,500,000$ \\
\hline 3 & $\begin{array}{l}\text { Pressure } \\
\text { Transmitter }\end{array}$ & $\begin{array}{l}\text { DP Transmitter } \\
\text { Yokogawa } \\
\text { EJX110A } \\
0.04 \text { accuracy } \\
90 \text { ms response } \\
\text { time } \\
\text { Range } 0-10000 \\
\text { mmh2o } \\
\text { Supply } 24 \text { VDC }\end{array}$ & $17,500,000$ \\
\hline 4 & $\begin{array}{l}\text { Temperature } \\
\text { Transmitter }\end{array}$ & $\begin{array}{l}\text { DP Transmitter } \\
\text { Yokogawa } \\
0.04 \text { accuracy } \\
90 \text { ms response } \\
\text { time } \\
\text { Range } 0-10000 \\
\text { mmh2o } \\
\text { Supply } 24 \text { VDC }\end{array}$ & $17,500,000$ \\
\hline 5 & $\begin{array}{l}\text { PLC Omron } \\
\text { CP1H PLC } \\
\text { CP1H- } \\
\text { X40DT-D } \\
\text { CP1HX40DT } \\
\text { D 24VDC } \\
\text { Input 40 I/0 } \\
\text { PC81 }\end{array}$ & $\begin{array}{l}\text { For Use With: } \\
\text { SYSMAC CP1H } \\
\text { Series } \\
\text { Number of I/O: } 40 \\
\text { Manufacturer } \\
\text { Series: CP1H } \\
\text { Number of Inputs: } \\
\text { 24 (DC) } \\
\text { Input Type: DC } \\
\text { Voltage Category: } \\
\text { 24 V dc } \\
\text { Output Type: } \\
\text { Transistor } \\
\text { Number of } \\
\text { Outputs: 16 } \\
\text { (Transistors) } \\
\text { Network Type: } \\
\text { Ethernet } \\
\text { Display Included: } \\
\text { Yes } \\
\text { Communication } \\
\text { Port Type: USB } 1.1 \\
\text { Program Capacity: } \\
\text { 20000 Steps } \\
\text { Programming } \\
\text { Interface: } \\
\text { Computer } \\
\text { Total Available } \\
\text { Memory: 20K } \\
\text { (Program } \\
\text { Memory) Steps, } \\
32 \mathrm{~K} \text { (Data } \\
\text { Memory) Words } \\
\text { Output Current: } \\
0.9 \text { (Per Common) } \\
\text { A, } 3.6 \text { (Per Unit) A, } \\
\text { 300 (Per Point) } \\
\text { mA }\end{array}$ & $4,150,000$ \\
\hline
\end{tabular}

\begin{tabular}{|c|c|c|c|}
\hline & & $\begin{array}{l}\text { Width: } 110 \mathrm{~mm} \\
\text { Length: } 150 \mathrm{~mm} \\
\text { Mounting Type: } \\
\text { DIN Track } \\
\text { Maximum } \\
\text { Operating } \\
\text { Temperature: } \\
+55^{\circ} \mathrm{C} \\
\text { Programming } \\
\text { Language Used: } \\
\text { Ladder Logic } \\
\text { Battery Backup: } \\
\text { Yes } \\
\text { Dimensions: } 150 \mathrm{x} \\
110 \mathrm{x} 85 \mathrm{~mm} \\
\text { Minimum } \\
\text { Operating } \\
\text { Temperature: } 0^{\circ} \mathrm{C} \\
\text { Depth: } 85 \mathrm{~mm} \\
\text { Number of } \\
\text { Communication } \\
\text { Ports: } 1 \\
\text { Scan Time: } 0.10 \\
\text { (Basic Instruction } \\
\text { Execution Time) s, } \\
0.15 \text { (Special } \\
\text { Instruction } \\
\text { Execution Time) s, } \\
0.7 \text { (Processing } \\
\text { Time) ms }\end{array}$ & \\
\hline 6 & Connector & $\begin{array}{l}\text { Superparis SS.304 } \\
\text { Male thread 1,500 }\end{array}$ & $5,000,000$ \\
\hline 7 & Control Valve & $\begin{array}{l}\text { Fisher Control } \\
\text { Valves } \\
\text { PCV / LCV } \\
\text { Size: 1" S/D 12" } \\
\text { Body: } \\
\text { WCB/WCC/SST } \\
\text { Design: ED, ET, EZ, } \\
\text { ES, EWD, EWS, } \\
\text { EWT, HPS, HPD, } \\
\text { HPT..etc. } \\
\text { Trim/Seat: 416SS } \\
\text { - 316SS - (option) } \\
\text { Characteristic: } \\
\text { Equal-Linear- } \\
\text { Quick Opening, } \\
\text {.Etc } \\
\text { Actuator Type: } \\
\text { 667 (Air To Open) } \\
\text { and 657 (Air To } \\
\text { Close) } \\
\text { Action: Pneumatic } \\
\text { Signal 3-15/6-30 } \\
\text { psig or Electric 4- } \\
\text { 20 mA } \\
\text { Actuator } \\
\text { Pneumatic } \\
\text { Diaphragm } \\
\text { Size: } 30-80 \\
\text { Accessories } \\
\text { (option): } \\
\text { * Positioner type: } \\
\text { 3582/3582i/DVC- } \\
\text { 6000 series } \\
\text { * Controller type: } \\
\text { 4150/4160 K } \\
\text { * PIC 4195 Series } \\
\text { * Regulator type: } \\
\text { 67 CFR }\end{array}$ & $35,000,000$ \\
\hline
\end{tabular}




\begin{tabular}{|c|c|c|c|}
\hline 8 & $\begin{array}{l}\text { Pressure } \\
\text { Gauge }\end{array}$ & $\begin{array}{l}\text { WIKA Pressure } \\
\text { Gauge } 4 \text { Inch } 16 \\
\text { Kg } \\
0-40 \text { Bar }\end{array}$ & 850,000 \\
\hline 9 & $\begin{array}{l}\text { Pressure } \\
\text { Switch }\end{array}$ & $\begin{array}{l}\text { Pressure Switch } \\
\text { SNS C104X } \\
(-0.06)-0.4 \mathrm{Mpa}\end{array}$ & 640,000 \\
\hline 10 & Orifice Plate & $\begin{array}{l}\text { 1. Pipe 14" (Flage } \\
\text { to Flange) } \\
\text { 2. Pipe 6" (Flange } \\
\text { to Flange) } \\
\text { 3. Pipe 20" } \\
\text { (Senior) } \\
\text { 4. Pipe 16" } \\
\text { (Flange to Flange) } \\
\text { 5. Pipe 8" (Senior) } \\
\text { 6. Pipe 22" } \\
\text { (Senior) } \\
\text { 7. Pipe 3" (Senior) }\end{array}$ & $\begin{array}{r}15,000,000 \\
7,500,000 \\
18,750,000 \\
17,500,000 \\
6,500,000 \\
20,000,000 \\
1,800,000\end{array}$ \\
\hline 11 & RTD & $\begin{array}{l}\text { RTD Pt100 Probe } \\
4^{\prime \prime} 200-400^{\circ} \mathrm{C}\end{array}$ & 300,000 \\
\hline 12 & $\begin{array}{l}\text { Temperature } \\
\text { Gauge }\end{array}$ & $\begin{array}{l}\text { Temperature } \\
\text { Gauge } \\
4 " \mathrm{x} \text { x } 100 \mathrm{~mm} \times 100 \\
{ }^{\circ} \mathrm{C}\end{array}$ & 890,000 \\
\hline 13 & Flow Meter & $\begin{array}{l}\text { K24 LCD Turbine } \\
\text { Digital Fuel Flow } \\
\text { Meter 1" } \\
\text { Model: K24 } \\
\text { Media: methanol } \\
\text { fuel kerosene } \\
\text { chemical liquid } \\
\text { urea water } \\
\text { Importers: } 1 \text { inch } \\
\text { internal thread } \\
\text { Length: } 103 \text { mm } \\
\text { Measurement } \\
\text { accuracy: } 1 \% \\
\text { Repeatability: } \\
0.5 \% \\
\text { Maximum } \\
\text { working pressure: } \\
20 \text { bar } \\
\text { Operating voltage: } \\
\text { 2.3-3.3V } \\
\text { Standby time: } 2 \\
\text { years } \\
\text { Flow range: } 10- \\
\text { 120 liter/min } \\
\text { Single count: } 0.00- \\
999.9 \\
\text { The total } \\
\text { cumulative } \\
\text { number: } 0.00- \\
999999.9 \\
\text { Unit: L/L, } \\
\text { gal/GAL, } \\
\text { pint/PTS, } \\
\text { quart/QTS } \\
\text { Single } \\
\text { measurement } \\
\text { cleared: reset }\end{array}$ & 780,000 \\
\hline 14 & ESDV & For Pipe 3" & $57,000,000$ \\
\hline 15 & $\begin{array}{l}\text { Presurre } \\
\text { Safety Valve }\end{array}$ & $\begin{array}{l}\text { Safety Valve } 317 \\
\text { 10K Cast Iron } \\
\text { With Lever 2" } \\
\text { DN50 }\end{array}$ & $4,125,000$ \\
\hline \multicolumn{3}{|c|}{ Total Cost } & $247,953,000$ \\
\hline
\end{tabular}

\section{Conclusion}

Based on the techniques of data collection, mapping and discussion analysis, the research can conclude the following matters: 1. Balun field can be used to improve the welfare of the community in Cepu and its surroundings. In addition, Balun field also has the potential as a field-campus for the Akamigas Polytechnic of Energy and Minerals in improving student skills and the lecturer competency.

2. Generating data on mechanical and instrumentation equipment, which will later be used to build a gas processing unit. As well as the estimated costs needed for its construction.

3. Produce a piping system path that will be used for gas distribution from the well to the processing unit, as well as the design results of mechanical equipment and instrumentation equipment at the Central Gas Processing Unit (CGPP).

\section{Acknowledgement}

The authors gratefully acknowledge the financial support of PEM Akamigas on this research.

\section{References}

[1] Ikatan Ahli Geologi Indonesia, 2008, Peta Wilayah Kerja Pertambangan (WKP).

[2] Horowitz, P., dan Hill, W., 1989, The Art Of Electronics, Edisi ke-2, Terbitan ke-6, Cambridge University Press, New York, Hal. 29-44.

[3] Lobanoff V.S.,1992, Centrifugal Pumps Design and Application, 2nd ed. McGrawHill, USA.

[4] Nasirwan, 2008, Optimasi Pengujian Pompa Seri dan Pararel, Jurnal Teknik Mesin Vol.5.No.1. Hal.15.

[5] R. R. Borikar and M. Subashini, 2018, Design of Distributed Control and Emergency Shutdown System for Urea and Ammonia Plant, MATEC Web of Conferences 225:02006.

[6] Sularso, 1999, Pompa dan Kompresor, Pradnya Paramita, Jakarta. 